\title{
Testis Torsiyonu ile Ortalama Trombosit Hacminin İlişkisi
}

\author{
$\underline{\text { Engin KÖLÜKCÜ̈}}{ }^{1}$, $\underline{\text { Serhat KOYUNCU }}^{2}$
}

\begin{abstract}
$\ddot{\mathbf{O z}}$
$\mathrm{Bu}$ çalışmada testis torsiyonlu hastalarda ortalama trombosit hacminin (MPV) klinik öneminin araştırılması amaçlanmıştır. Bu retrospektif çalışmada iki çalışma grubu analiz edildi. Grup 1; skrotal eksplorasyon ile testis torsiyonu tanıs1 konulan 31 hastadan oluşmaktaydı. Grup 2; kontrol grubu olarak belirlendi. Kontrol grubuna; üroloji polikliniğine rutin kontrol amaciyla başvuran ve tamamen sağlıklı 38 erkek hasta dahil edildi. Grup 1 ve 2 arasındaki MPVdeğerleri istatiksel olarak karşılaştırıldı. Çalışmaya alınan 69 hastanın yaş ortalamas $10,87 \pm 8,99$ yıl idi. Grup 1 ve 2 için MPV değerleri sırası ile 8,33 $\pm 1,08$ ve $9,7 \pm 1,49$ olarak hesapland. Grup 1'de hesaplanan MPV değerleri Grup 2 ile karşılaştırıldığında istatiksel olarak anlamlı olarak düşük olarakizlendi $(p<0,001)$. Testis torsiyonlu hastalarda MPV değeri önemli ölçüde azalmaktadır. Dolayısıyla MPV değerinin testis torsiyonu tanısında destekleyici bir kriter olarak kullanabileceğini düşünmekteyiz.
\end{abstract}

Yayın Bilgisi

Gönderi Tarihi: 08.11.2018

Kabul Tarihi: 07.01.2019

Online Yayın Tarihi: 31.12 .2019

DOI: $10.26453 /$ otjhs. 480490

Sorumlu Yazar

Engin KÖLÜKÇÜ

Tokat Devlet Hastanesi, Üroloji

Kliniği, Türkiye

Tel: +905354002385

E mail: drenginkolukcu@ gmail.com

Anahtar kelimeler: Testis, torsiyon, trombosit

\section{The Role of Mean Platelet Volume in the Diagnosis of Testicular Torsion}

\author{
$\underline{\text { Engin KÖLÜKCÜ̈}}{ }^{1}, \underline{\text { Serhat KOYUNCU }}^{2}$
}

\begin{abstract}
The aim of this study is to examine the clinical importance of mean platelet volume (MPV) in patients with testicular torsion. In this retrospective study, two study groups were analyzed. Group I consisted of 31 patients diagnosed with testicular torsion following scrotal exploration. Group II was determined as control group. A total of 38 healthy male patients visited the urology clinic for their routine controls were included in the study. MPV values between Groups I and II were compared statistically. The mean age of the 69 patients included in the study was $10.87 \pm 8.99$ years. MPV values were calculated as $8.33 \pm 1.08$ and $9.7 \pm 1.49$ for Group I and II, respectively. MPV values in Group I were statistically lower than that in Group II $(\mathrm{p}<0.001)$. The MPV value is significantly reduced in patients with testicular torsion. Therefore, we think that MPV values can be used as a supporting criterion in the diagnosis of testicular torsion.
\end{abstract}

Article Info

Received: 08.11.2018

Accepted: 07.01.2019

Online Published: 31.12.2019

DOI: $10.26453 /$ otjhs. 480490

Corresponding Author Engin KÖLÜKÇÜ

Tokat Devlet Hastanesi, Üroloji Kliniği, Türkiye

Tel: +905354002385

E mail: drenginkolukcu@gmail.com

Keywords: Testicular, torsion, platelet

${ }^{1}$ Tokat Devlet Hastanesi, Üroloji Kliniği, Türkiye

${ }^{2}$ Tokat Gaziosmanpasa Üniversitesi Tıp Fakültesi Acil Tıp Anabilim Dalı, Tokat, Turkiye

\section{INTRODUCTION}

Testicular torsion is defined as the deterioration in testicular perfusion as the spermatic cord rotates around itself. It is demonstrated as the most important cause of acute scrotum. Delay in diagnosis or failure of treatment algorithms result in testis loss. ${ }^{1}$ It is estimated that 400 boys a year lose a testicle due to testicular torsion in the $\mathrm{UK}^{2}$ On the other hand, testicular necrosis might have adverse effects on male fertility and hormonal functions. ${ }^{3}$ Although testicular torsion can be seen in all age groups, it is frequently seen in neonatal and post pubertal periods. ${ }^{4,5}$

The majority of patients diagnosed with testicular torsion attended emergency clinics with sudden onset of testicular pain. However, accompanying clinical conditions such as scrotal volume increase, redness of scrotal skin, abdominal pain in the lower quadrant, nausea and vomiting can also be seen. Therefore, testicular torsion should definitely 
be ruled out in patients presenting with testicular pain. ${ }^{6}$ In the diagnosis of testicular torsion, color doppler ultrasonography of the scrotum has an important place together with detailed anamnesis and meticulous examination of genitourinary system. But none of these three methods have $100 \%$ sensitivity and specificity. ${ }^{7}$ This may result in unnecessary invasive procedures in patients presenting with testicular pain. ${ }^{8}$

Previously, platelets were thought to be only responsible for hemostasis. Today, however, studies show that they are also critical in the regulation of inflammatory reactions. Platelet volume is directly related to the enzymatic and metabolic activities of platelets. Mean platelet volume (MPV) is a highly useful parameter predicting the mean platelet size that can be easily calculated with an automated hematology analyzer and documented in hemogram results in most clinics. As a result of all these features, MPV has been studied as an indicator of inflammation in many different diseases such as rheumatoid arthritis, ankylosing spondylitis, colon, ovarian and thyroid cancers. ${ }^{9,10}$

All the data were accessed by a retrospective analysis of the patient records and only those whose data were fully recorded were included in the study. Patients who had active infection, history of previous surgery, any chronic disease, received non-steroidal antiinflammatory, anticoagulant, anti-aggregant therapy, attended after a blunt or penetrating trauma were excluded from the study. The study was approved by Local Ethics Committee (Tokat, 2018 November, Confirmation number: 13- 06)

Demographic data and complete blood count (CBC) parameters of all patients were examined. All blood samples were collected by ethylene diamine tetra acetic acid (EDTA) anticoagulation. $\mathrm{CBC}$ analyses were performed with the same device that was checked and maintained at regular intervals. (Mindray BC-6800, China). The MPV values determined by this device for each patient were recorded. In the study, the reference range for the MPV value of the device used in the data analysis was 7.5-12.1 femtoliter (fL).

\section{Statistics}

Descriptive statistics have been made in order to obtain information about the general characteristics of the study. Data of continuous variables were given as arithmetic mean and standard deviation. The conformity of continuous variables to normal distribution was investigated by Kolmogorov Smirnov test. Data with $p \leq 0.05$ were considered to fit to normal, and those with $\mathrm{p}>0.05$ deemed to have non-normal distribution. The variables that meet the normal distribution were compared with 'independent samples t-tests' and those with non-normal distribution with Mann Whitney $\mathrm{U}$ test. $\mathrm{P}$ values less than 0.05 were considered to be statistically significant 
Calculations were performed using a statistical software (IBM SPSS Statistics 21, SPSS Inc., an IBM Co., Somers, NY) program.

\section{RESULTS}

The mean age of 69 patients was $10.87 \pm 8.99$ years. The mean age of patients in Group I and II was $11.52 \pm 3.54$ and $10.34 \pm 2.79$ years, respectively. There was no significant difference between the groups in terms of the mean age $(\mathrm{p}>0.05)$ (Table 1$)$.

Testicular torsion was diagnosed after scrotal exploration in each patient in Group I. In all patients, torsion was observed in single testis, either right or left. Before the surgical intervention, detailed anamnesis was taken and a thorough physical examination was performed. Afterwards, the testis and its accessories were examined with color doppler ultrasonography of the scrotum by the radiologist. The decision for surgery was made after a final evaluation by the urology specialist. The same procedure was performed for each patient. Patients diagnosed with testicular torsion in consequence of the surgical intervention were included in the study. Testicular pain was the main complaint of all patients. In addition to the complaint of testicular pain, one patient had fever, 7 had abdominal pain and 8 had nausea and vomiting. On the physical examination, sensitivity in the spermatic cord was observed in 5 patients and nonspecific findings such as local erythema, tenderness and scrotal swelling were observed in 15 . On the other hand, Ger sign, defined as retraction at scrotal base due to torsion and Prehn sign, persistent pain despite scrotum elevation were detected in $74.2 \%$ of the patients in Group I. 23 of the patients in the study were observed to have left testicular torsion. While the testes in 21 patients were detorsioned to maintain testicular viability, others had to undergo orchiectomy.

The mean MPV value of the patients analyzed in our study was $9.09 \pm 1,48$. These values were $8.33 \pm 1.08$ and $9.7 \pm 1.49$ for Group I and II respectively. The MPV values in Group I were statistically significantly lower compared to that in Group II $(\mathrm{p}<0.001)$ (Table 1).

\section{DISCUSSION}

Acute scrotum pathologies consist of a group of diseases that develop in the scrotal region with sudden onset of pain, swelling and redness. The causes of acute scrotum include many clinical conditions such as epididymitis, epididymo-orchitis, abscess, testicular torsion, trauma and testicular cancer. Among these etiological factors, infective pathologies such as orchitis and epididymitis are the most common clinical pictures. Although testicular torsion constitutes approximately $25 \%$ of these cases, it is considered to be the most important and urgent acute scrotal pathology due to its results. $^{11}$

The historical development of testicular torsion shows that the first testicular torsion 
case was presented by Hunter in the 1800s. ${ }^{12}$ Recent scientific publications indicate that the annual incidence of testicular torsion under 18 years of age is estimated to be 3.8 per 100.000. ${ }^{13}$ The main mechanism of testicular torsion occurs when the testis turns around the spermatic cord. As a result, spermatic veins are obstructed and testicular blood supply is impaired. The level of tissue damage is directly related to the degree and duration of torsion. When tissue damage occurs after ischemia, inflammatory chain reactions occur as a response in the body. Therefore, early surgical intervention is critical for protecting patients from ischemic damage. In this context, a number of studies were published on this subject in previous years and the application of testicular detorsion to cases in the time interval of 4 to 8 hour is generally considered to be an acceptable time interval to recover the affected testicle. ${ }^{14}$

The need for urgent evaluation of the acute scrotum is obvious. However, accuracy of the diagnosis is highly important for preventing testicular tissue damage and/or unnecessary surgical procedures. ${ }^{15}$ Following the detailed anamnesis and careful physical examination, color doppler ultrasonography of the scrotum is also important for patients presenting with acute scrotum. It is a low-cost, rapid, noninvasive method frequently used in emergency clinics. However, depending on personal interpretation of the radiologist who evaluates this diagnostic method, it is possible to encounter some incorrect results. In their study, Yapanoğlu et al. concluded that sensitivity and specificity of doppler ultrasonography were $94 \%$ and $100 \%$, respectively, in the diagnosis of testicular torsion. ${ }^{16}$ In another study, the sensitivity of doppler ultrasonography in patients with acute scrotum was $88.9 \%$ and specificity was $98.8 \% .^{7} \quad$ In another study evaluating 43 patients with prediagnosis of testicular torsion through doppler scrotal ultrasonography following detailed anamnesis, physical examination and surgical exploration, no testicular torsion was observed in 8 patients $(18.6 \%) .{ }^{17}$ All the cases in our study consisted of patients diagnosed with testicular torsion after surgery. For this reason, the reliability of the imagings made before the testis torsion in our study could not be evaluated.

Clinicians are concerned about unnecessary surgical interventions in patients presenting with acute scrotum. This has led researchers to investigate simple and feasible parameters with rapid results that will strengthen the diagnosis of testicular torsion. In this context, CBC parameters that are routinely studied before each surgery were the focus of attention. Platelets play a various roles in human body, including thrombosis, angiogenesis and inflammation. ${ }^{18} \mathrm{MPV}$, a measure of platelet size, is calculated by analyzers for routine complete blood count and 
documented in CBC test results. ${ }^{19}$ In the past, however, MPV was often ignored by clinicians when examining $\mathrm{CBC}$ results. However, as the number of clinical studies on MPV has recently been increasing in the current medical literature, it has turned out to become a parameter considered by many physicians.

Considering the studies on CBC parameters in past years, it is observed that the MPV value is generally increased in vascular events such as cerebrovascular disease and peripheral vascular disease and remained low in cases of inflammatory events such as ulceratic colitis and rheumatoid arthritis. ${ }^{20}$ A large number of proinflammatory cytokines are released under conditions of inflammation. Increased proinflammatory cytokines in the environment cause thrombocytosis. This situation may lead to an increase in the number of platelets and a decrease in MPV., ${ }^{9,18}$ Several clinical studies performed in previous years evaluated the relationship between MPV and inflammation. Beyazit et al. evaluated 184 patients, 114 of whom were diagnosed with acute pancreatitis, and concluded that MPV was lower in patients diagnosed with acute pancreatitis compared to the control group. ${ }^{21}$ In another study, Yüksel et al. reported that MPV values were significantly lower in patients with active ulcerative colitis. ${ }^{22}$ Similarly, a retrospective study evaluating patients with adnexal torsion revealed that MPV was lower in patients with torsion. ${ }^{23}$ On the other hand, Köleli evaluated patients with adnexal torsion and suggested that the MPV value was of no clinical importance in diagnosis and prognosis. ${ }^{24}$ In another study by İncebiyık et al., it was reported that MPV values were significantly lower in female patients with pelvic inflammatory disease. ${ }^{9}$ Albayrak et al. concluded that the MPV value was significantly lower in the acute appendicitis group when compared to the control group in their study evaluating 432 patients of whom 226 had acute appendicitis. ${ }^{25}$ Similarly, in a study conducted by Billici et al., the MPV value was lower in the group diagnosed with acute appendicitis in comparison with that in the control group. ${ }^{26}$ In another one, Güneş et al. evaluated the relationship between testicular torsion and hematologic parameters, and concluded that MPV did not have a predictive role in the diagnosis of testicular torsion, but the neutrophile lymphocyte ratio showed high sensitivity and specificity in predicting the diagnosis. ${ }^{8}$ In our study, testicular torsion was diagnosed in 31 cases and total of 69 cases was evaluated. In this retrospective study comparing MPV values of patients diagnosed with testicular torsion with completely healthy individuals. MPV values of patients with testicular torsion were found to be in accordance with our literature and significantly statistically low.

\section{Limitations of the Study}


Among the limitations can be counted that the analyses were made retrospectively on patient records, risk factors for testicular torsion could not be revealed and the number of samples was low due to lack of multicenter data. Acute scrotal pathologies could not be compared among themselves due to the lack of acute scrotum patients other than testicular torsion. This situation can be shown as the major deficiency of the study.

\section{Conclusions}

Our clinical observations in the study demonstrated that the diagnosis of testicular torsion may be related to MPV. We are of the opinion that this easy, cost-effective and repeatable parameter can be used as a supporting criterion in the diagnosis of testicular torsion. However, we believe that our study results should be supported by prospective, more randomized, multicenter and controlled studies.

\section{REFERENCES}

1. Cuckow PM, Frank JD. Torsion of the testis. BJU Int. 2000;86(3):349-353. Doi: 10.1046/j.1464-410x.2000.00106.x6.

2. Bennett S, Nicholson M, Little T. Torsion of the testis: why is the prognosis so poor? Br Med J. 1987;294:824.

3. Bartsch G, Frank S, Marberger, Mikuz G. Testicular torsion: late results with special regard to fertility and endocrine function. J Urol. 1980;124(3):375-358. Doi: 10.1016/S0022-5347(17)55456-7.
4. Liu CC, Huang SP, Chou YH, et al. Clinical presentation of acute scrotum in young males. Kaohsiung $\mathrm{J}$ Med Sci. 2007;23(6):281-286. Doi:10.1016/S1607551X(09)70410-3.

5. Barada JH, Weingarten JL, Cromie WJ. Testicular salvage and age-related delay in the presentation of testicular torsion. J Urol. 1989;142(3):746-748. Doi: 10.1016/S0022-5347(17)38875-4.

6. Memik Ö, Kayıkçı A, Akyüz O, Yaşar M. Testicular Torsion: Case Report. Konuralp Medical Journal. 2012;4(1):35-37.

7. Baker LA, Sigman D, Mathews RI, Benson I, Docimo SG, An analysis of clinical outcomes using color doppler testicular ultrasound for testicular torsion. Pediatrics. 2000;105:604-607.

8. Güneş $M$, Umul $M$, Altok $M$, et al. Predictive role of hematologic parameters in testicular torsion. Korean $\mathbf{J}$ Urol. 2015;56(4):324-329.

Doi: 10.4111/kju.2015.56.4.324.

9. Incebiyik A, Seker A, Vural M, Hilali NG, Camuzcuoglu A, Camuzcuoglu $\mathrm{H}$. May mean platelet volume levels be a predictor in the diagnosis of pelvic inflammatory disease? Wien Klin Wochenschr. 2014;126:422-426. Doi: 10.1007/s00508-014-0560-2.

10. Pyo JS, Sohn JH, Kang G. Diagnostic and prognostic roles of the mean platelet volume in malignant tumors: a systematic 
review and meta-analysis. Platelets. 2016;27(8):722-728.

Doi:

10.3109/09537104.2016.1169265.

11. D'Andrea A, Coppolino F, Cesarano E, et al. US in the assessment of acute scrotum. Crit Ultrasound J. 2013;5(Suppl 1):S8. Doi: 10.1186/2036-7902-5-S1-S8.

12. Nöske HD, Kraus SW, Altinkilic BM, Weidner W. Historical milestones regarding torsion of the scrotal organs. J Urol. 1998;159(1):13-16.

13. Zhao LC, Lautz TB, Meeks JJ, Maizels M. Pediatric testicular torsion epidemiology using a national database: incidence, risk of orchiectomy and possible measures toward improving the quality of care. J Urol. 2011;186(5):20092013. Doi: 10.1016/j.juro.2011.07.024.

14. Schneck F and Bellinger M: Abnormalities of the testes and scrotum and their surgical management. In: Campbell-Walsh Urology, 9th ed. Edited by AJ Wein, LR Kavoussi, AC Novick et al. Philadelphia: Saunders-Elsevier; 2007; vol 4, p 4592.

15. Ciftci AO, Senocak ME, Tanyel FC, Büyükpamukçu N. Clinical predictors for differential diagnosis of acute scrotum. Eur J Pediatr Surg. 2004;14(5):333-338. Doi:10.1055/s-2004-821210.

16. Yapanoğlu T, Aydın HR, Adanur Ş, Özkan P, Demirel A, Okyar G. Our Thirteenth-year Experience with
Testicular Torsion in Children. Eurasian J Med. 2007;39:164-168.

17. Sayan A, Can M. Our eight year experience with testicular torsion of children and adolescents. İzmir Dr. Behçet Uz Çocuk Hast. Dergisi. 2016;6(3):174178. Doi:10.5222/buchd.2016.174.

18. Gasparyan AY, Ayvazyan L, Mikhailidis DP, Kitas GD. Mean platelet volume: a link between thrombosis and inflammation? Curr Pharm Des. 2011;17(1):47-58.

Doi:10.2174/138161211795049804.

19. Sandhaus LM, Meyer P. How useful are $\mathrm{CBC}$ and reticulocyte reports to clinicians? Am J Clin Pathol. 2002;118: 787-793. Doi: 10.1309/CQGG-HY0ULRKL-GLMP.

20. Pyo JS, Cho WJ. Mean Platelet Volume, Platelet Distribution Width, and Platelet Count in Varicocele: A Systematic Review and Meta-Analysis. Cell Physiol Biochem. 2016;38(6):2239-2246. Doi:10.1159/000445579.

21. Beyazit Y, Sayilir A, Torun S, et al. Mean platelet volume as an indicator of disease severity in patients with acute pancreatitis. Clin Res Hepatol Gastroenterol. 2012;36(2):162-168.

Doi:10.1016/j.clinre.2011.10.003.

22. Yüksel O, Helvaci K, Başar O, et al. An overlooked indicator of disease activity in ulcerative colitis:mean platelet volume. 
Platelets. 2009;20(4):277-281.

Doi:10.1080/09537100902856781.

23. İncebıyık A, Uyanıkoğlu H. Is there a role mean platelet volume in the diagnosis of patients with adnexal torsion? Dicle Med J. 2017;44(4):333-337. Doi:10.5798/dicletip.362315.

24. Köleli I. Mean Platelet Volume in Early Diagnosis of Adnexal Torsion. Balkan Med J. 2015;32(4):410-413.

Doi:10.5152/balkanmedj.2015.151092.
25. Albayrak Y, Albayrak A, Albayrak F, et al. Mean platelet volume: a new predictor in confirming acute appendicitis diagnosis. Clin Appl Thromb Hemost. 2011;17(4):362-366.

Doi:10.1177/1076029610364520.

26. Bilici S, Sekmenli T, Göksu M, Melek M, Avci V. Mean platelet volume in diagnosis of acute appendicitis in children. Afr Health Sci. 2011;11(3):427-432 
Table 1. Comparison of parameters according to group.

\begin{tabular}{lccc}
\hline Variable & Group 1(testis torsiyon) $(\mathbf{n}=31)$ & Group 2 $($ control $)(\mathbf{n}=38)$ & p-value \\
Age $(\mathbf{Y})$ & $11.52 \pm 3.54$ & $10.34 \pm 2.79$ & $\mathrm{p}>0.05$ \\
MPV & $8.33 \pm 1.08$ & $9.7 \pm 1.49$ & $\mathrm{p}<0.001$ \\
\hline$Y ;$ Year & $M P V ;$ Mean platelet volume & &
\end{tabular}

Table 2. Data of patients diagnosed with testicular torsion. 


\begin{tabular}{lll}
\hline Variable & & Values \\
Surgical side & Right & 8 \\
Result of surgery & Left & 23 \\
& Detorsion & 21 \\
& Orchiectomy & 10 \\
Application complaints & Testicular pain & $31(\% 100)$ \\
& Fever & $1(\% 3.3)$ \\
& Abdominal pain & $7(\% 22.6)$ \\
Physical examination findings & Nausea and vomiting & $8(\% 25.8)$ \\
& Sensitivity in the spermatic cord & $5(\% 16.1)$ \\
& & \\
& Nonspecific findings (local & $15(\% 48.4)$ \\
& temperature, scrotal swelling and & \\
& tenderness) & $23(\% 74.2)$ \\
\hline The pre- and post-operative datas of the patients diagnosed with testicular torsion were analyzed.
\end{tabular}

